\title{
Variation on sandbar of tributary in Xiaolangdi Reservoir on Yellow River, China
}

\author{
LI Tao ${ }^{1,2}$ ZHANG Jun-hua'² GAO Guoming ${ }^{1}, 2$ Ma Huaibao ${ }^{3}$ \\ ${ }^{1}$ Yellow River Institute of Hydraulic Research,YRCC,Zhengzhou, China,450003; ${ }^{2}$ State Key Lab oratory of Water Resources and \\ Hydropower Engineering Science, Wuhan University, Wu han, China,430072)
}

\begin{abstract}
Sandbar development would stop the water and sediment exchange between main river and tributary and even influence the normal reservoir opeartion. From the surveyed data of reservoir built many years ago, it shows that when there is a bar in tributary mouth, the tributary volume below the bar will become nullification during the period of flood control or water and sediment regulation of reservoir. There are more tributaries in Xiaolangdi reservoir than the others that it occupies $41.3 \%$ of the total initial volume of tributary volume. Obviously, the effective use of tributary volume has been important influenced by comprehensive utilization efficiency of reservoir scheduling, such as flood control, sedimentation reduction and comprehensive utilization. Results of Xiaolangdi Reservoir mobile-bed physical model experiments show that tributary is equivalent to lateral extension of river bed, the tributary intrusion deposition process have strongly relations with the factors, such as original topography, river bed deposition shape and its regime, process with input discharge and input sediment, and method of reservoir regulation. The variation trends of main river and tributary terrain forecasted by model test are basically in accordance with field surveyed data. The results could be used for research, design, and forecasting of reservoirs in sediment-laden river.
\end{abstract}

\section{Introduction}

Tributary sandbar often occurs at the mouth of tributary which lie in a disadvantageous site. With reservoir operation,if there are little possibility for tributary flood and poor water and sediment input match from main river,large scale sandbar forms at the mouth of tributary with interrupting the water and sediment exchange between main river and tributary and influencing the reservoir operation precision.For example,sandbar development in the mouth of Guishui river in Danjiangkou reservoir,stops the water supply from the reservoir. Sandbar development in the mouth of Wei river indued by the Yellow river,heavens the flood threat and water environment pollution in the Wei river valley. Sandbar development in the mouth of Yuan river and Longmen river brings many problems.From the bulit reservoirs with long term practical operation,sandbar stops the water and sediment exchange between main river and tributary ,and reservoir capacity of tributary can not be used effiency.Even the reservoir general utilization benefit would be heavily hindered.By now,water and sediment movement law have not been controled and modeled.From the study on the physical model of Xiaolangdi reservoir by Zhangjunhua ${ }^{[9-14]}$, the deposition in tributary which is mainly induced by turbidity current had been found with further study on the backward flow between main river and tributary. With the help of field surveyed data from built reservoirs are analyzed in analogy, the research results of sandbar variation in long series model tests in the first stage of late retainning sediment period of xiaolangdi reservoir is condensed.The results could be technically refered by the sediment-laden river planed,designed and operated

\section{Overview of Xiaolangdi Reservoir and its physical model}

Xiaolangdi Reservoir belongs to canyon-Reservoir, and the upper reach is wider in than that in lower reach. According to the plane modality, the reservoir could be divided into two parts. The upper reach is from Station Sanmenxia to Section HH37 with the length $60.92 \mathrm{~km}$ and bottom width of river valley about $200 \mathrm{~m}$ to $400 \mathrm{~m}$. The lower reach is with the length $62.49 \mathrm{~km}$ and bottom width of river valley about $800 \mathrm{~m}$ to $1400 \mathrm{~m}$,especially bottom width of river valley about $300 \mathrm{~m}$ between $27 \mathrm{~km}$ and $31 \mathrm{~km}$ to the dam. The normal water storage level is below $275 \mathrm{~m}$ with the original volume 12.750 billion cubic metre and branch volume 5.263 billion cubic metre which occupies $41.3 \%$ ratio of the total volume. The quantity of branches which volume is bigger than 0.1 billion cubic metre is 11.These branches all distribute the lower reach of the reservoir. The main characteristics are listed in Tab.1.

The designed effective storage capacity of reservoir is 5.1 billion cubic metre. The effective storage capacity and the quantity of branch sediment storage occupy both the 
correspondent total quantity above $30 \%$.It will influence the general utilization heavily including reservoir antiflood and sedimentation reduction whether the branch storage is effectivly utilized.The tributary has a small daily discharge and almost blanking.some sand and little stone will flow downstream when short periond flood comes during the flood period.According with analying,the transporting quantity of bed material and suspend sand per y quantity ear is respectively 0.27 million tons and 2.97 million tons.it could be ignored with the input sediment quantity. Therefore, the branch sediment storage could meet the designed quantity or not, which is decided by the quantity of the incoming sediment from the main to the tributary.Morever,the sedimentation distribution of the branch mainly influence the effective storage capacity. When the sediment from the main stream comes into the branch, sand bar often occurs at the mouth of branch. The storage capacity of branch below the sand bar elevation is not be effective utilized. Even it would become invalid volume which neither intercept sediment nor participate in normal operation.According to the surveyed data before the flood period in 2015,the difference between sand bar and its river bed is beyond 10 meters in the biggest branch named River Zhenshui.

The physical model of Xiaolangdi Reservoir covers about $124 \mathrm{~km}$ from Station Sanmenxia to the dam,which has the total main river volume and $90 \%$ of branch volume.it had been designed by use of similar condition on the sediment-laden reservoir movable bed model and river bed boundary feature.the main scale is listed in the Tab.2, which is decided by the validated experiments with the field data from Xiaolangdi reservoir. The model is designed by the vertical scale 100 and horizontal scale 60.The Zhengzhou thermal power plant fly ash is chose as model sand.

Tab.1 Main characteristic of branchesin Xiaolangdi Reservoir

\begin{tabular}{llllllll}
\hline river name & $\begin{array}{l}\text { Day } \\
\mathrm{u}\end{array}$ & $\begin{array}{l}\text { Zhens } \\
\text { hui }\end{array}$ & $\begin{array}{l}\text { Shiji } \\
\mathrm{ng}\end{array}$ & $\begin{array}{l}\text { Dongy } \\
\text { ang }\end{array}$ & $\begin{array}{l}\text { Xiya } \\
\mathrm{ng}\end{array}$ & $\begin{array}{l}\text { Yan } \\
\mathrm{xi}\end{array}$ & $\begin{array}{l}\text { Boqi } \\
\mathrm{ng}\end{array}$ \\
\hline $\begin{array}{l}\text { Length } \\
\text { between } \\
\text { mouth and }\end{array}$ & 3.9 & 18.0 & 22.1 & 31.0 & 41.3 & 54.0 & 57.6 \\
the & & & & & & & \\
$\begin{array}{l}\text { dam } / \mathrm{km} \\
\text { Original }\end{array}$ & & & & & & & \\
$\begin{array}{l}\text { volume } / \text { bi } \\
\text { llion } \mathrm{m}^{3}\end{array}$ & 0.57 & 1.767 & 0.48 & 0.3111 & 0.23 & 0.40 & 0.13 \\
\hline
\end{tabular}

\begin{tabular}{ccccccc}
\hline \multicolumn{7}{c}{ Tab.2 Main scale table } \\
\hline Horizontal & vertical & Velocity & roughness & $\begin{array}{c}\text { settling } \\
\text { velocity }\end{array}$ & $\begin{array}{c}\text { Sediment } \\
\text { concentration }\end{array}$ & time \\
\hline 300 & 60 & 7.75 & 0.88 & 1.34 & 1.50 & 44.9 \\
\hline
\end{tabular}

\section{Model experiment condition}

Based on the surveyed surface topography of Xiaolangdi Reservoir on October,2007,with 17 a water-sediment series from 1960 to 1976 designed the 2020 level, experiment on operation mode of Xiaolangdi Reservoir in its second stage of sediment retaining had been carried in use of operation mode which can achieve sediment pluriennial regulation and scour due to dropping pond water level occasionally.

The operation mode of Xiaolangdi Reservoir mainly reflectes in scouring due to dropping pond water level occasionally with large discharge and operating on combination with gradually hightening pond water level for flushing fine sediment and retaining coarse sediment and water and sediment regulation.Selection of opportunity for scour due to dropping pond water level occasionally decided on the period, when reservoir sedimentation comes 4.2 billion cube metre ,the $\max$ regulating discharge is $3700 \mathrm{~m}^{3} / \mathrm{s}$ and the min regulating discharge is $400 \mathrm{~m}^{3} / \mathrm{s}$. Then flood process is made with the minimal water storage meets 1.3 billion cube metre. When the input discharge

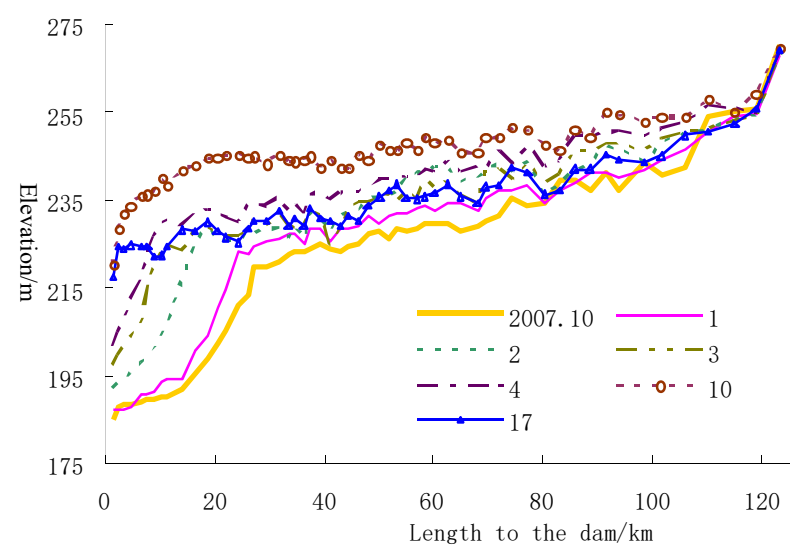

Fig.1 Chart of process on main channel talweg prediction ahead 2 days is not less than 2600 $\mathrm{m}^{3} / \mathrm{s}$,reservoir door is opened for scoured or flood process is made by water supplement with storage. When the sum discharge of the input and Station Heishi and Station Wuzhi downstream is more than $4000 \mathrm{~m}^{3} / \mathrm{s}$, the reservoir is shifted into the anti-flood operation state.

\section{Landform variation process on water- sediment series model experiment}

\subsection{Landform variation process in Main River}

The reservoir initial boundary condition is delta landform in October,2007.The peak of delta is $27.2 \mathrm{~km}$ to the dam. The fore slope reach below the peak of delta has a sharply increaseing water depth,sharp decreasing velocity and sediment-carrying capacity sharp drop.On the process of experiment,much sediment settle down and delta continue going to the dam.At the No.5 year, the peak of delta transformed into cone and only erosive funnel existed in the front of the dam.After that,during the process of reservoir water and sediment regulation,river bed gradully rised and the slope was to slow down. At the No.14 year,in the flood period,the flood beach face elevation came to 254 metre and the accumulated deposition was about 7.55 billion cube metre.Then the sediment retaining period was over and normal operation period began. At the No.17 year, the operation mode of scour due to dropping pond water level occasionally began, the combination action of head-cut scour and scour along the river made the channel elevation dropped and high beach face and deep channel formed. Process on main channel talweg is showed in Fig.1. 


\subsection{Landform variation process in tributary}

The input sediment of tributary in Xiaolangdi Reservoir could be ignored.The deposition mainly orgined from the main river flow backward.the original slope of main tributary in the reservoir is normally about $1 \%$. the original slope of the largest original volume of tributary is about $0.56 \%$.the backward deposition after reservoir regulatin changes the tributary landform and river bed composition. Vertical adjustment of the general trend of slope gradually reduce to horizontal,and inverted slope at last.the tributary mostly shows inverted slope at the experiment ends.

During the process of expeiment, each tributary has different natural conditions, and the deposition landform and process are not identical, even have larger difference.

The original volume of the tributary of Zhenshui at the elevation of 275 metre is about 1.767 billion cube metres.And the length of its back water is bigger than $20 \mathrm{~km}$.the width of section at the mouth is about $600 \mathrm{~m}$, while the width upstream is bigger than $2500 \mathrm{~m}$. flow width of the backward water and sediment along the river increase sharply and velocity decreasing rapidly.Sediment deposit heavily along the river.the backward turbid water flows further away from the mouth with less sediment.But the flow width increases along the river.during the sediment retaining period of the reservoir,the river bed rises slowlu with the main river deposition face rising.The discrepancy in elevation has an increasing trend.

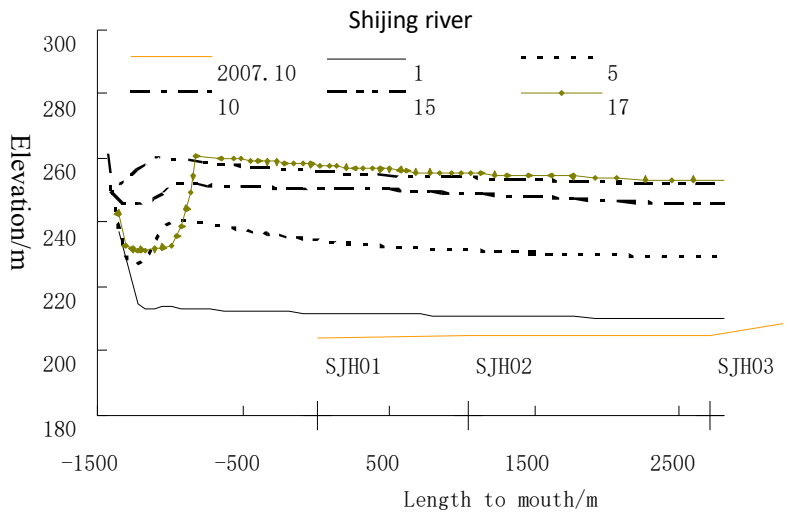

Fig.2 process talweg of Shing River

The tributary of Shijing,which is about $22.1 \mathrm{~km}$ away from the dam, has a different plane landform with tributary of Zhenshui. The original volume of it is about 0.48 billion cube metres. At the elevation of 275 metre,the length of its back water is close to $10 \mathrm{~km}$. The width of section at the mouth is more than $2000 \mathrm{~m}$, while the width upstream is about $500 \mathrm{~m}$. The width of section at the mouth is in favor of main river crossrange backward flowing. The inner width for sediment deposition gradually decreases and river bed rises respectively.

Some branches which have little volume deposit rapidly.For example,the original volume is only about 0.0621 billion cube metre with the the length of its back water less than $5 \mathrm{~km}$ at the elevation of 275 metre.The volume was rapidly filled with sediment.

The variation process of tributary talweg shows that, even the sediment retaining period ends, the main river bed states in the movable balance. The branch river bed still rises slowly with the turbid water flowing backward.
So it can make the deposition face difference between the main river and branch trending to be less. For example, compared with the talwegs of the tributary of Zhenshui in No.15 and No.17,the mouth elevation has no change and deposition face $5 \mathrm{~km}$ way from the mouth rises about $4 \mathrm{~m}$.

The cross section landform often rises parrallel with the main river bed deposition.when the reservoir operate in scour due to drop the pond water level and main river bed sharply drops, deposition face close to the mouth of tributary drops either and the obvious channel forms. The tributary of Dayu, which is about $4 \mathrm{~km}$ away from the dam, has a parrallel deposition before No.10 in the experiment process. After No.17 with scour due to drop the pond water level, the first section appears obvious beach and channel. The altitude difference of both is same to that at the mouth.it is showed in Fig.3.



Fig.3 process talweg of Section of Dayu River

\subsection{Rationality analysis of experiment results}

Due to the obvious difference among the tributary topographies in the reservoir,the deposition morphology and process is apparently different in the series experiment.the outstanding problems of sand bar occur in tributary Zhenshui.After the experiment,the altitude difference on longitudinal direction is more than $20 \mathrm{~m}$.In order to demonstrate the possibility, the measured data of the built reservoirs is analogy analyzed below.

\section{Guanting Reservoir}

Guanting Reservoir, which lies in the Yongding river,was built as first large-scale key project in 1950s in the sediment-laden river.The water storage formally operates in October,1955. The designed total volume of the reservoir is 2.27 billion cubic metre, volume of tributary Guishui river 1.29 billion cubic metre which occupies $57 \%$ ratio of the total volume. The water input quantity of main river occupies $95 \%$ ratio of the total input, while the sediment input all comes from main river. At the same time, the deposition in tributary Guishui is due to the flow backward from the main river. To 1998, deposition in Guanting reservoir was about 0.65 billion cube metre.the deposition ratio of Yongding river and Guishui river was respectively $88.5 \%$ and $11.5 \%$.The proportion of Guishui volume increases little by little. The longitudinal deposition landform of Yongding River, which is main river of Guanting Reservoir, is delta which gradually advances to the dam. After 1980, the sediment input 
decreases suddenly and the talweg of main river changes little. While sand bar at the mouth of Guishui River increases, the altitude difference between the sand bar and the inner Guishui river bed also increases, with adverse slope increasing to $8.0 \%$ in 1997 .

The formation and development of sand bar at the mouth are related with factors like reservoir boundary conditions, the conditions of water and sediment and main river deposition development etc..The width of Guishui river mouth is narrow with the vaviation between $1.5 \mathrm{~km}$ and $2 \mathrm{~km}$.the elevation increases rapidly. While the inner Guishui river width is 4 times more than the mouth width. The water input of Guishui river occupies $5 \%$ of the total input,so it's hard to burst through the early deposition and cumulative deposition occurs in the mouth.This weakens the reservoir regulation ability.some responsible units provided reservoir sediment trearment programs including sandbar excavated and dredged, sediment guiding dike,comprehensive treatment in front of the dam,channeling beside the bank and sediment guided to the Guishui river etc. Those results shows that people have realized that natural flow conditions can not remove the sand bar problem in a short term.

Water and sediment input conditions and boundary conditions between main river and tributary Zhenshui river in Xiaolangdi reservior is similar with that between main river named Yongding river and tributary Guishui river in Guanting reservior.There is almost little water and sediment input in Zhenshui river where is all deposited by backward flow from the main river.The width of the Zhenshui river mouth is narrow and nearly 600 metres, while the inner width grows suddenly nearly 2500 metres to 3000 metres.Morever,deposited height of the main river bed in the mouth of Zhenshui river is more than 60 metres, which is much larger than that of 20 metres in the mouth of Guishui river.

In the experiments, the deposition in Zhenshui river mostly forms by backward flow which belongs to open channel flow regime. While depoisition before 1980 was due to density current flow regime and after 1980 due to open channel flow regime in Guishui river.the field data show that backward flow in open channel flow regime takes a more prominent role in sandbar formation.For an example,main river and tributary backward flow each other by density current flow regime in Guanting reservoir from 1955 to 1980 .Section Gui1000 near the Guishui river mouth rised about 10 metres, while the inner Section Gui1009 was about 6 metres.Main river and tributary backward flow each other by open channel flow regime in Guanting reservoir from 1981 to 1998 .Section Gui1000 near the Guishui river mouth rised about 6 metres, while the inner Section Gui1009 rised only about16 metres. The ratio of the two periods and two parts respectively is 10:6 and 6:1.in the series experiment on the provised program on reservoir operation in the second sediment retaining period in physical model of Xiaolangdi reservoir,the backward flow belongs to open channel flow regime in all years except the first year with density current flow regime.If the landform after the flood period is looked as the demarcation point for mainly backward flow which belongs to open channel flow regime, then the relevant characteristics about the tributary Zhenshui river in Xiaolangdi reservoir and tributary Guishui river in Guanting reservoir are listed in Tab.3.

Tab.3 comparison on relevant characteristics about the tributary Zhenshui river in Xiaolangdi reservoir and tributary Guishui river in Guanting reservoir

\begin{tabular}{|c|c|c|c|c|c|c|c|c|}
\hline \multirow[t]{2}{*}{ name } & \multicolumn{2}{|c|}{ Width/m } & \multicolumn{2}{|c|}{$\begin{array}{l}\text { Water and sediment } \\
\text { quantity occupies the } \\
\text { total input }\end{array}$} & \multicolumn{4}{|c|}{ Deposit height $/ \mathrm{m}$} \\
\hline & mouth & inner & water & sediment & $\begin{array}{l}\text { backward } \\
\text { flow regime }\end{array}$ & mouth & inner & mouth/inner \\
\hline \multirow{2}{*}{$\begin{array}{l}\text { Guishui } \\
\text { river }\end{array}$} & \multirow{2}{*}{$\begin{array}{l}1500 \sim \\
2000\end{array}$} & \multirow{2}{*}{$\begin{array}{l}6000 \sim \\
8000\end{array}$} & \multirow{2}{*}{$5 \%$} & \multirow{2}{*}{$\approx 0$} & $\begin{array}{l}\text { density } \\
\text { current flow }\end{array}$ & 10 & 6 & 1.67 \\
\hline & & & & & $\begin{array}{l}\text { open channel } \\
\text { flow }\end{array}$ & 6 & 1 & 6.0 \\
\hline \multirow{2}{*}{$\begin{array}{l}\text { Zhenshui } \\
\text { river }\end{array}$} & \multirow{2}{*}{600} & \multirow{2}{*}{$\begin{array}{l}2500 \sim \\
3000\end{array}$} & \multirow{2}{*}{$\approx 0$} & \multirow{2}{*}{$\approx 0$} & $\begin{array}{l}\text { density } \\
\text { current flow }\end{array}$ & 37.5 & 21.5 & 1.74 \\
\hline & & & & & $\begin{array}{l}\text { open channel } \\
\text { flow }\end{array}$ & 56.1 & 14.2 & 3.95 \\
\hline
\end{tabular}

The above data including the surveyed deposit quantity before 2007

\section{Danjiangkou Reservoir}

Danjiangkou Reservoir is parallel reservoir which is composed of main river named Hanjiang river and tributary named Danjiang river.The dam site lies to below the converge of Danjiang river into Hanjiang river about $0.8 \mathrm{~km}$. The similarity to the Xiaolangdi reservoir is many branches. There are more than 400 items including large and small branches in the Hanjiang reservoir.the reservoir volume of Hanjiang river is about 5.463 billion cube metres which occupies $60.2 \%$, while the tributary volume is about 3.612 billion cube metres which occupies $39.8 \%$

From 1960 to 2003, the reseroir deposition volume in main river of Hanjiang river was 1.189 billion cube metres,which occupies $85.6 \%$ of the total deposition volume of Hanjiang river.The reservoir volume of main river damaged $21.7 \%$ by deposition. At the same time, the total tributary deposition quantity is about 0.2 billion cube metres, which occupies $14.4 \%$ of the total deposition volume of Hanjiang river.The tributary reservoir volume damaged $5.5 \%$ by deposition.

Yuanhe river,which is $67.6 \mathrm{~km}$ away from the dam,lies in the deposited heavily district of Hanjiang river bed that rised in a high extent.The deposition height which is corresponding with the mouth is about 28.7 metre.the tributary longitudinal slope near the mouth became from the positive slope $9 \%$ to backward slope $4.0 \%$.The altitude difference between the mouth and tributary river 
bed is to $12.3 \mathrm{~m}$, and the reach is in the deposition developing phase,so the sandbar will increase with the deposition of main river beach ${ }^{[16-17]}$.

\section{Analysis on the factors on tributary sandbar}

Tributary amounts to the horizontal extend of the main river bed.the backward flow process on the tributary bed including deposition quantity and formation is closely related to the factors including the tributary natural landform conditions, main river deposition landform,main river regime,water and sediment input process and reservoir operation etc..

1 Tributary natural landform conditions. The reservoir volume of tributary is big and wide in plane form.But the reservoir sediment retaining volume of tributary deposits slowly,sandbar problem is prominent with longitudinal height differenc large. When the water and sediment from the main river goes through the convergence, the tributary is backward flowed laterally.in general,it is not better for sediment being backward flowing with larger tributary reservoir volume,narrower mouth and longer backwater.

2 main river deposition landform.inthe period of reservoir sediment retaining,main river deposition process is usually same as the process of the sedimentation delta moving downstream. When the peak of main river deposition delta lies in front of the convergence of the tributary,turbidity current occurs below the delta peak with the water and sediment input in the normal circumstance.So when the current goes through the tributary mouth,turbidity current backward flow into the tributary. The deposition of tributary bed is plane with turbidity current backward flow.the slope occurs due to the sediment deposited along the river.When the delta peak is proposed ahead and stride the tributary mouth,sandbar is obviously formed with the deposition face rising suddenly in the main river bed and tributary mouth.Above the main river deposition delta,the obvious beach and channel is modeled.The tributary mouth,which amounts to the main river beach,flood discharge in main river can laterally flow into tributary only when it is larger than the channel conveyance capacity.

main river regime variation is regulated with the reservoir regulation process, water and sediment input conditions and both combination. This process is random.If the main current of main river is away from tributary mouth,the sediment concentration will obviously decrease in a large extent with a long way above the beach after backward flow. Therefore,during the process of scour due to reservoir water pond level lowering,main channel is scoured and deepened,and range on sidewall collapse decreases along the transversal direction.

3 water and sediment input process. Whether backward flowing in turbidity current regime oropen channel regime.Tributary deposition due to backward flow is heavier with that The flood period lasted longger,the order larger and sediement concentration higher.If turbidity current occurs in both main river and tributary with long flood period,this makes not only tributary reservoir volume full of deposition,but also suspend sediment depositing from the backward flow and water seperated out back to the main river.So the turbid water from main river and tributary water continously changes.If the backward flow belongs to the open channel regime,only can long period and large flood overbank and flow into the tributary.If the water level in tributary is low, the water level difference makes the backward flow velocity larger, and even sours and lowers the sandbar.This would accelerate the backward flow process.

4reservoir operation.It is one of the most important factors for reservoir operation process that influence the reservoir deposition form and sediment transporting regime.It also decides the sediment transporting regime in the backward flow between main river and tributary and boundary conditions. The reservoir volume for regulating is larger,some medium and small flow without overbank in open channel flow regime will form turbidity current and be over the sandbar flowing into the tributary which adds the possibility for tributary backward flow.Therefore,during the random sediment flushing process, tributary sandbar scours correspondingly and river channel which runs through between main river and tributrary forms. This is good for backward flow due to the subsequent flow and the tributary volume utilizaiton.

5 water and sediment exchange of backward flow between main river and tributary.the process on tributary longitudinal seciton variation showed that tributary deposition along the river is relatively uniform if backward flow occured due to turbidity current.For example,tributary Dayuhe river(Fig.4), whose delta peak of main river lied on the mouth upstream with turbid water flowing into tributary as turbidity current regime and plane longitudinal section from $1^{\text {st }}$ year to $4^{\text {th }}$ year in series experiment. To the $5^{\text {th }}$ year, when delta peak of main river came to the mouth downstream,sandbar suddenly formed and was prodimenent. The trend was accorded with the field data.For example,tributary Zhenshui river, longitudinal section slope ranged from the positive to the adverse which had an increasing trend.The max longitudinal height difference is about $1.7 \mathrm{~m}$ after flood period in $2008,3.18 \mathrm{~m}$ before flood period in 2009 , and $4.29 \mathrm{~m}$ before flood period in 2010. In 2011, $\max$ longitudinal height difference is about $10.18 \mathrm{~m}$ before flood period, where the elevation of the main river deposition face rised $12.79 \mathrm{~m}$ to $213.24 \mathrm{~m}$ near the Zhenshui river mouth. While the elevation of tributary deposition face of section ZS5 rised $6.9 \mathrm{~m}$ to $203.56 \mathrm{~m}$, where is about $5 \mathrm{~km}$ away from the Zhenshui river mouth upstream.

What needs to be pointed out is that in the sediment retaining phase of reservoir,the deposition face rised gradually.For the tributary Zhenshui river which has a larger volume,the height difference between main river and tributary deposition face increased little by little due to the range rised in tributary less than that in the main river.Afer the sediment retaining phase of reservoir is end, when river bed never continously rised and lied in the state of dynamic balance,the tributary deposition face 
rised with main river flow overbank or backward flow through the linkage channel.This makes the height difference tending to decrease.The series experment results shows that the comparison between the $15^{\text {th }}$ year and $17^{\text {th }}$ year is the mouth elevation changed little and the deposition elevation rised $4 \mathrm{~m}$ where are $5 \mathrm{~km}$ away from the mouth in tributary Zhenshui river.

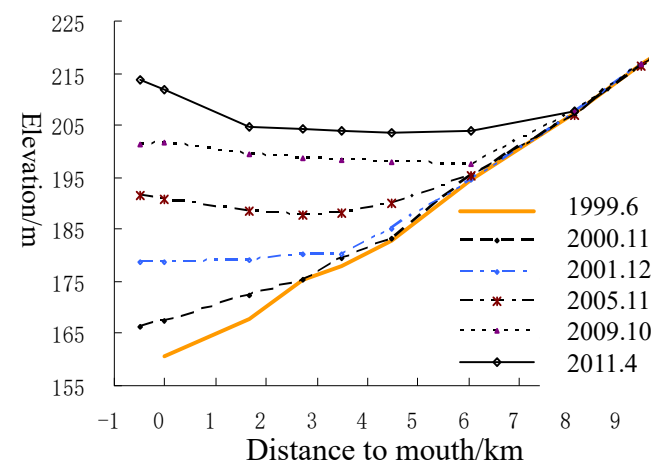

Fig.4. Chart of process on talweg of Zhenshui River

\section{Conclusion}

Sandbar formation of reservoir tributary is decided by reservoir boundary conditions, water and sediment input conditions, reservoir operation process and combination among those conditions. Many influent factors and local sediment transporting regime make the tributary deposition landform and variation process random, diversity and complexity.

The model is designed by the vertical scale 100 and horizontal scale 60 .The Zhengzhou thermal power plant fly ash is chose as model sand. It is accord with the movable bed model law in sediment-laden reservoir in Yellow river. Series model tests show that the main river talweg is delta deposition landform and whether the tributary sandbar forms is decided by the site where it lies.This can be known by the variation of vertical talweg process of Shijing river and Zhenshui river.the surveyed data show that the height difference is to $10.18 \mathrm{~m}$ in Zhenshui river which is higher than that of $6 \mathrm{~m}$ in Guishui river in Guanting reservoir.

From the formation of sandbar in Zhenshui river and Guishui river, the factors include many conditions like natural topography,deposition form of main river,water and sediment input,reservoir operation and water and sediment exchange of backward flow between main river and tributary.

It can provide technical support for controlling sediment deposit site and distribution in sediment retaining phase, being full use of tributary volume, and prolonging the life in reservoir sediment retaining to study the response mechanics between tributary deposition landform due to backward flow and influent factors in reservoir. At the same time, it also enriches the subject context in hydraulic, river sediment dynamics and river model technics. The next study should provide the compute mode of tributary backward flow which is based on theory of the river sediment dynamics to improve the level of understanding.

\section{ACKNOWLEDGEMENT}

The study is supported by ational nature science foundation of China (No. 51679103,51309110、51179072、 51509100 ), and Yellow River Institute of Hydraulic Research Central level, scientific research institutes for basic R \& D operating expenses of special funds (compact number:HKY-JBYW-2018-02). We thank anonymous reviewers for their patience and time for reviewing this article.

\section{Reference :}

1. HU Chun-hong, WANG Yan-gui, ZHANG Shi-qi,et al. Sedimentation and water and sediment regulation of Guanting Reservoir[M]. Beijing: China water conservancy and hydropower press, 2003.

2. Jiao Enze..Sediment Experiment and Research on Reservoir Sanmenxia [M]. Yellow River Conservancy Press.2011.

3. LIU Fa-zhong, WANG Hong-zheng, YANG Kai, et al. Characteristics and problems of tributary deposition in Danjiangkou Reservoir [J]. Yangtze River, 2006,37(8):26-28.

4. HAN Qi-wei. Reservoir sedimentation[M]. Beijing: Science press, 2003.

5. WU Chao; HUANG Guo fu; YANG Yong quan. Study on Lateral Flow Exchange Between Tributary and Main Channel During Flood Routing [J]. JOURNAL OF SICHUAN UNIVERSITY (ENGINEERING SCIENCE EDITION), 2000, 32(4):11-14.

6. WANG Xiao-yan. Law analysis of flowing backward from Yellow River to Weihe River in flood season. WATER RESOURCES \& WATER ENGINEERING, 1994(1):32-37.

7. LI Jing-yi. Risk Evaluation and Influence Analysis of Flowing Backward From Main Stream in Xiaobei of Huanghe(Yellow) River to Lower Reacher of Weihe River. Scientia Geographica Sinica, ,2011,31(8): 947951.

8. HUA Zu-lin, RUI Xiao-fang, HUANG Guo-ru, et al. A Method for Velocity Calculation of Downdraft Reach under Lack of Hydrologic Data[J]. Advances In Water Science, 2001, 12(2):210-214.

9. FENG Xiao-xiang, ZHANG Xiao-feng, XIE Zuo-tao. Calculation of Sediment at the Tail of Tributary under Condition of Flow Backwards [J]. China Rural Water and Hydropower, 2005(2):53-56.

10. ZHANG Jun hua, WANG Yan ping, ZHANG Hong wu. Numerical simulation of deposition process of the Xiaolangdi Reservoir in the early stage of operation [J]. Journal of Hydraulic Engineering, 2002(7):110116.

11. Li Tao, Zhang Junhua, Ma Huaibao etc. Preliminary Analysis on the Backflow Length to the Tributaries of 
the Xiaolangdi Reservoir [C]. Proceedings of the 4th International Yellow River Forum on Ecological Civilization and River Ethics, 2010(2):223-228

12. ZHANG Jun-hua, Li Shu-xia, CHEN Shu-kui, et al.Review of research and application on density current of Xiaolangdi Reservoir in the Yellow River [C]. Proceedings of symposium on density current problems, 2006(10):205-213.

13. Chen Shukui, Ma Huaibao, Li Kunpeng etc. Study on full utilization of tributary storage of Xiaolangdi Reservoir [C]. 4th International Yellow River Forum on Ecological Civilization and River Ethics Technical Paper Abstracts, 2010(2):446.

14. Junhua ZHANG, Shukui CHEN, Shuxia LI etc. Numerical and physical modelings of Xiaolangdi Reservoir on the Yellow River [C]. Proceedings of the Ninth International Symposium on Sedimentation. 2004(10):974-980

15. ZHANG Jun-hua, CHEN Shu-kui, MA Huai-bao, et al. Report on model test of operational mode of Xiaolangdi reservoir for flood control and sedimentation reduction during later period of sediment retention [R]. Yellow River Institute of Hydraulic Research, YRCC, 2010.

16. WANG Ting, CHEN Shu-kui, MA Huai-bao, et al. Distribution of deposition in Xiaolangdi Reservoir [J]. Sediment Research, 2011(5):60-66.

17. LIU Fa-zhong, WANG Hong-zheng, YANG Kai, et al. Deposition characteristics and problems of tributary storage in Danjiangkou Reservoir [J]. Yangtze River, 2006, 37(8):26-28.

18. ZHANG Hou-yu, HU Jia-qing, LANG Li-ming, et al. Sedimentation characteristics and problems of Danjiangkou Reservoir [J]. Yangtze River, 2005, 36(1):27-31. 